\title{
Chapter 4 \\ Reconstruction Support for the Farmland Struck by Tsunami
}

\author{
Itsuo Goto and Kaisei Inagaki
}

\begin{abstract}
Reconstruction support of the disaster-stricken areas in the city of Soma, Fukushima Prefecture, was started in May 2011. Sediment transported from the sea by the tsunami was from 5 to $10 \mathrm{~cm}$ thick on surface of the paddy fields. The tsunami sediment was mixed with the original soil of the paddy fields, and mole drains were formed to improve water drainage toward the lower layer. Subsequently, rainwater alone was used for salt removal. However, the pyrite in the soil had gradually oxidized until the $\mathrm{pH}$ dropped to 3.8, so converter slag was applied to neutralize the sulfuric acid. In May 2012, rice was transplanted into paddies from which the salt had been removed. On September, 10.7 t brown rice was harvested. The yield of brown rice harvested per hectare was $6.3 \mathrm{t}$, about $20 \%$ higher than the amount before the disasters.
\end{abstract}

Keywords Tsunami $\bullet$ Tsunami sediments $\bullet$ Salt removal $\bullet$ Converter slag $\bullet$ Soma City

\subsection{Conditions Observed in Soma's Post-tsunami Farmland and Basic Aims of Reconstruction Initiatives}

\subsubsection{Reconstruction Support Starting May 2011}

The authors entered the disaster-stricken areas in the city of Soma, Fukushima Prefecture, on May 1, 2011, as participants in the Tokyo University of Agriculture East Japan Assistance Project. In Soma, the support base for the project (Fig. 4.1), we witnessed the devastation of the landscape caused by the giant tsunami, and it was beyond our imagination. What struck us particularly was the large number of pine trees that had previously grown on sandbanks in Matsukawaura Lagoon and were now piled up as debris in the paddies extending to its west (Fig. 4.2). Littered

I. Goto $(\square) \cdot$ K. Inagaki

Department of Applied Biology and Chemistry, Tokyo University of Agriculture,

1-1-1 Sakuragaoka, Setagaya-ku, Tokyo 156-8502, Japan

e-mail: igoto@nodai.ac.jp 


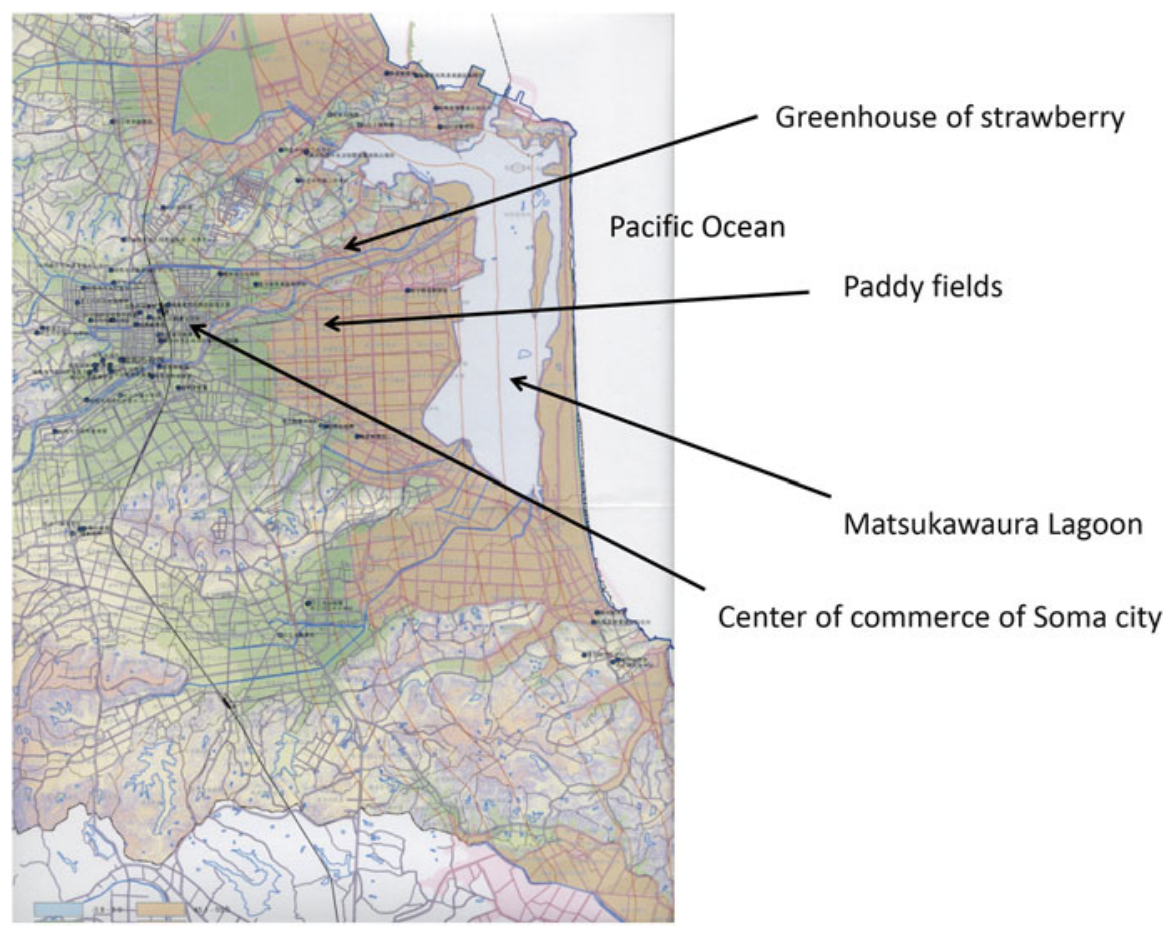

Fig. 4.1 Map of Soma City affected by the tsunami

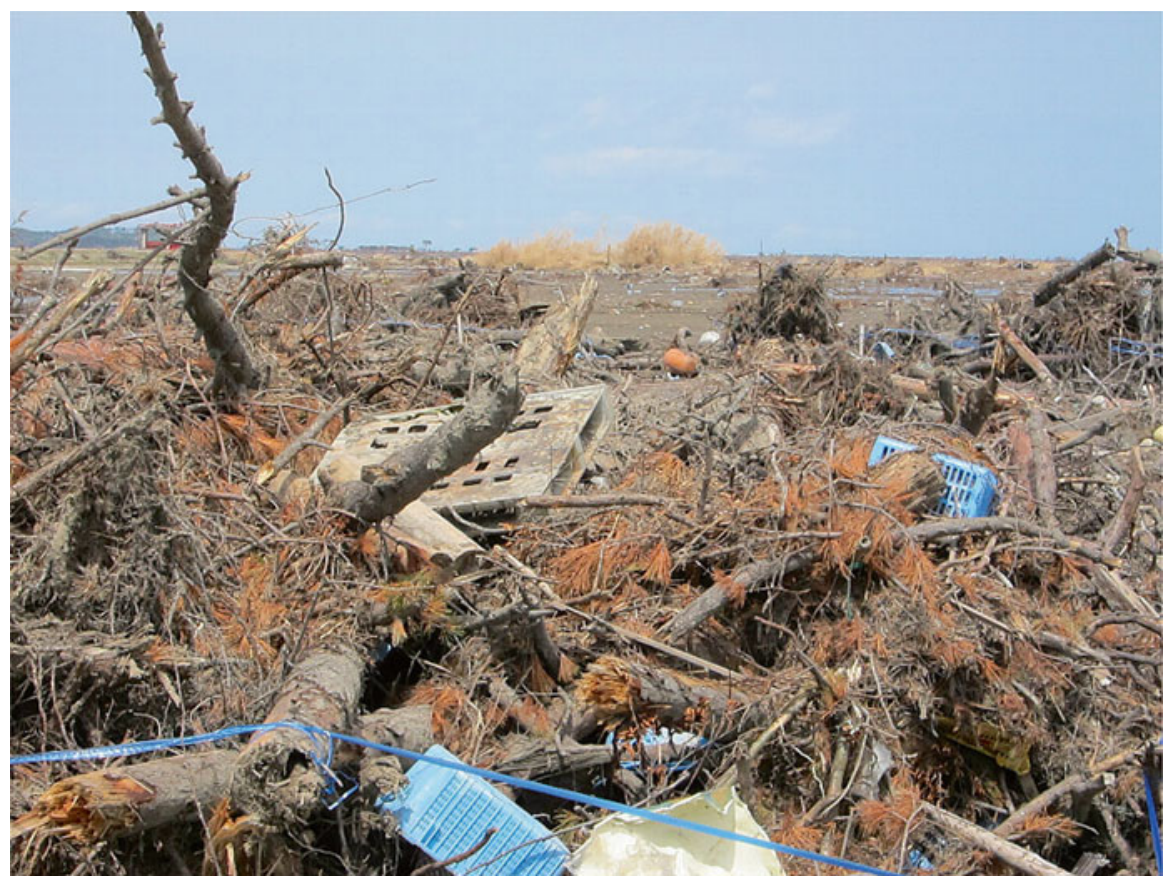

Fig. 4.2 Paddy fields struck by tsunami adjacent to Matsukawaura Lagoon 
among these trees were cars, tractors, and washed-up fishing boats. The local farmers were devastated, bemoaning the fact that it would take years before the paddy fields could be restored to their original state. Under the huge amount of debris was a thick layer of accumulated tsunami sediment containing vast quantities of salt transported from the sea by the massive tsunami.

\subsubsection{Classification of Post-tsunami Farmlands Based on the First Field Survey}

Based on a field survey undertaken in May, we classified the farmlands into the following three types.

1. Paddy fields adjacent to the coast that were still flooded because of land subsidence and that contained a large amount of debris

2. Paddy fields that had been affected by the tsunami, but had started to dry up by the survey in May, were located several kilometers from the coastline and contained little debris

3. Sites such as greenhouses and upland fields that were affected by the tsunami but contained no debris

\subsubsection{Properties of Tsunami Sediment Accumulated on the Surface of Tsunami-Hit Farmlands}

(a) Soil chemical properties of tsunami sediment

The soil chemical properties of the tsunami sediment collected during the field survey from May 1 to 3, 2011, are shown in Table 4.1.

The sodium chloride content estimated from the exchangeable sodium content reached 2.9-5.7 \%, with a high electrical conductivity (EC) of 12-24 mS/cm serving as an indication of the salt concentration. The sodium chloride content in seawater is approximately $3 \%$, but tsunami sediment with almost twice this amount of salt was observed (Table 4.1). However, high levels of salt content were limited to the clay layer on the surface of the tsunami sediment, with the salt content in the sand layer underneath showing a sharp progressive decline. The cation-exchange capacity (CEC) in the clay layer of the tsunami sediment was about $30 \mathrm{mEq} / 100 \mathrm{~g}$, which tended to be higher than in the soil of either paddy fields or greenhouses. In addition, the soils contained a large amount of exchangeable magnesium and potassium.

Because the tsunami sediment contains substances transported from the seabed, we were concerned about the possibility of acidification similar to that found in soil on reclaimed land from the sea. We therefore measured the total sulfur content and 


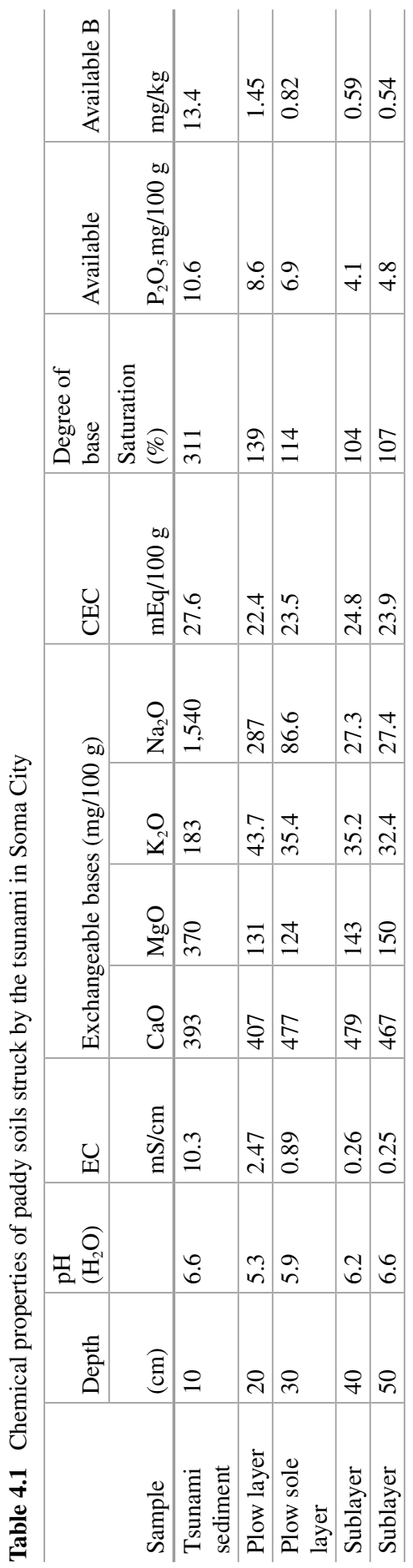


Table 4.2 Total sulfur content and $\mathrm{pH}$ of tsunami sediments

\begin{tabular}{l|l|l|l}
\hline Sampling site & Total S \% & $\mathrm{pH}\left(\mathrm{H}_{2} \mathrm{O}\right)$ & $\mathrm{pH}\left(\mathrm{H}_{2} \mathrm{O}_{2}\right)$ \\
\hline Paddy field I & 1.27 & 6.6 & 2.3 \\
\hline Paddy field II & 1.19 & 6.5 & 2.5 \\
\hline Paddy field III & 0.34 & 5.9 & 2.6 \\
\hline Paddy field IV & 1.11 & 7.3 & 2.2 \\
\hline Upland field & 1.14 & 7.5 & 2.3 \\
\hline
\end{tabular}

Table 4.3 Concentration of trace elements of tsunami sediments and farmland soils

\begin{tabular}{l|l|l|l|l|l|l|l|l|c}
\hline $\begin{array}{l}\text { Classification } \\
\text { of land }\end{array}$ & Sampling site & Sample & $\begin{array}{l}\text { Depth } \\
(\mathrm{cm})\end{array}$ & $\mathrm{Cd}$ & $\mathrm{As}$ & $\mathrm{Zn}$ & $\mathrm{Cu}$ & $\mathrm{Ni}$ & $\mathrm{Cr}$ \\
\hline Paddy field & $\begin{array}{l}\text { Kashiwazaki } \\
\text { I }\end{array}$ & $\begin{array}{l}\text { Tsunami } \\
\text { sediment }\end{array}$ & 10 & 0.65 & 8.62 & 162 & 33.2 & 20.6 & 60.0 \\
\hline Upland field & $\begin{array}{l}\text { Kashiwazaki } \\
\text { II }\end{array}$ & $\begin{array}{l}\text { Tsunami } \\
\text { sediment }\end{array}$ & 3 & 0.48 & 8.19 & 124 & 24.6 & 19.0 & 50.3 \\
\hline Paddy field & Kabaniwa & $\begin{array}{l}\text { Tsunami } \\
\text { sediment }\end{array}$ & 5 & 0.32 & 6.81 & 46.1 & 10.7 & 32.2 & 26.7 \\
\hline Greenhouse & Wada & $\begin{array}{l}\text { Tsunami } \\
\text { sediment }\end{array}$ & 0.7 & 0.39 & 4.30 & 110 & 19.9 & 21.0 & 71.5 \\
\hline & Ridge & 20 & 0.35 & 4.81 & 96.7 & 18.5 & 21.5 & 63.9 \\
\hline & Ridge & 30 & 0.32 & 4.40 & 92.8 & 19.8 & 22.6 & 55.9 \\
\hline & Ridge & 45 & 0.39 & 5.67 & 181 & 38.6 & 49.4 & 72.3 \\
\hline Greenhouse & Wada & $\begin{array}{l}\text { Ridge } \\
\text { Tsunami } \\
\text { sediment }\end{array}$ & 10 & 0.46 & 8.82 & 130 & 37.1 & 27.8 & 52.8 \\
\hline & Furrow & 30 & 0.23 & 3.38 & 133 & 32.5 & 45.2 & 61.9 \\
\hline Paddy field & Wada & $\begin{array}{l}\text { Tsunami } \\
\text { sediment }\end{array}$ & 5 & 0.43 & 8.97 & 113 & 32.2 & 22.2 & 47.6 \\
\hline & $\begin{array}{l}\text { Plow } \\
\text { layer }\end{array}$ & 20 & 0.34 & 3.99 & 107 & 38.5 & 35.8 & 58.3 \\
\hline & $\begin{array}{l}\text { Plow sole } \\
\text { layer }\end{array}$ & 30 & 0.28 & 4.31 & 93.7 & 36.1 & 44.1 & 59.1 \\
\hline
\end{tabular}

$\mathrm{pH}\left(\mathrm{H}_{2} \mathrm{O}_{2}\right)$ of the soil collected. As shown in Table 4.2, the total sulfur contents of the tsunami sediments were about $1 \%$ and $\mathrm{pH}\left(\mathrm{H}_{2} \mathrm{O}_{2}\right)$ was 2.2-2.6. As soil with a $\mathrm{pH}\left(\mathrm{H}_{2} \mathrm{O}_{2}\right)$ of 3 or less is defined as an acid sulfate soil, the sediment transported by the tsunami was assessed to be a potential source of acid sulfate soil.

(b)Harmful elements contained in the tsunami sediment

We analyzed the levels of harmful elements such as cadmium and arsenic in the tsunami sediment and the soil layers underneath collected from the survey sites already mentioned (Table 4.3).

The cadmium content in the tsunami sediment ranged from 0.32 to $0.65 \mathrm{mg} / \mathrm{kg}$, with an average value of $0.39 \mathrm{mg} / \mathrm{kg}$. The content in the soil layers underneath 
ranged from 0.28 to $0.39 \mathrm{mg} / \mathrm{kg}$, with an average value of $0.29 \mathrm{mg} / \mathrm{kg}$. Although the cadmium level in the sediment was higher than that of the underlying soil, it was equivalent to the median value of $0.39 \mathrm{mg} / \mathrm{kg}$ in farmland soil across the country.

The amount of arsenic in the tsunami sediment and soil was less than $10 \mathrm{mg} / \mathrm{kg}$ for both, which was the same as or lower than the background value in the soil. The amounts of zinc, copper, lead, nickel, and chrome in the tsunami sediment were almost the same as those in the soil.

\subsection{Reconstruction Support Policy for Post-tsunami Farmlands}

\subsubsection{Mix Soil Layers Without Removing Tsunami Sediment}

The tsunami sediment contained as much as $10-20 \mathrm{mS} / \mathrm{cm}$ of salt and a large amount of water-soluble boron (B) at $20 \mathrm{mg} / \mathrm{kg}$, both of which substantially hinder the growth of vegetation. Meanwhile, the cation-exchange capacity (CEC) was higher than that of the plow layer, with large amounts of exchangeable magnesium and potassium serving as soil nutrients. Harmful elements such as cadmium and arsenic were a particular concern, but their levels were not found to be higher than those of the plow layer.

We knew that the salt and boron in the soil could be leached out with water, while soil acidification caused by the oxidation of pyrite could be corrected by applying lime material. We therefore decided to remove salt by mixing the sediment with the original soil and without removing the soil introduced by the tsunami.

\subsubsection{Use Converter Slag as Lime Material to Remove Salt}

The chloride ions in the salt are anions that exist as water-soluble ions not adsorbed by the soil colloids, but the sodium ions exist as water-soluble sodium in the form of counterions to chloride and exchangeable sodium adsorbed by the soil colloids. Therefore, when lime material is applied and mixed thoroughly with the soil, a cation-exchange reaction occurs between the calcium ions in the slag and the exchangeable sodium, allowing the exchangeable sodium to be converted to watersoluble sodium. For this reason, converter slag generated as a by-product during the steel manufacturing process in steelworks is used as lime material. The raw materials of converter slag such as iron ore, coal, and limestone contain no harmful components; the main component is calcium silicate, whereas the secondary components include micronutrients such as iron, manganese, and boron, in addition to free lime (quicklime) and magnesium. As a result, even if the $\mathrm{pH}\left(\mathrm{H}_{2} \mathrm{O}\right)$ is raised to about 7.5 or higher by using converter slag in the soil, it is unlikely to cause a deficiency of micronutrients in the crops. In addition, converter slag acts more slowly than calcite 
or dolomite in mitigating soil acidification, and can therefore also be used to counter soil acidification caused by the oxidation of pyrite in the tsunami sediment.

\subsection{Reconstruction Support for Restart of Strawberry Cultivation}

\subsubsection{Just in Time}

In the disaster zone affected by the tsunami, local farmers naturally assumed that they would have to remove the tsunami sediment, known as hedoro or "sludge," that had accumulated on the surface of the soil in strawberry greenhouses (Fig. 4.3). In fact, sludge removal work was scheduled to take place a few days after we first visited a strawberry farm that we were assisting. However, we managed to persuade the farmer that there was no need to remove the tsunami sediment. Instead, the first thing we did was to expose the soil to the rain by ripping off the plastic rooftops of the greenhouses and the mulching on ridges, which had been untouched since March 11. After we had finished analyzing the soil to confirm that there were no problems associated with harmful elements, the farmers themselves mixed the tsunami sediment with the original soil in June (Fig. 4.4).

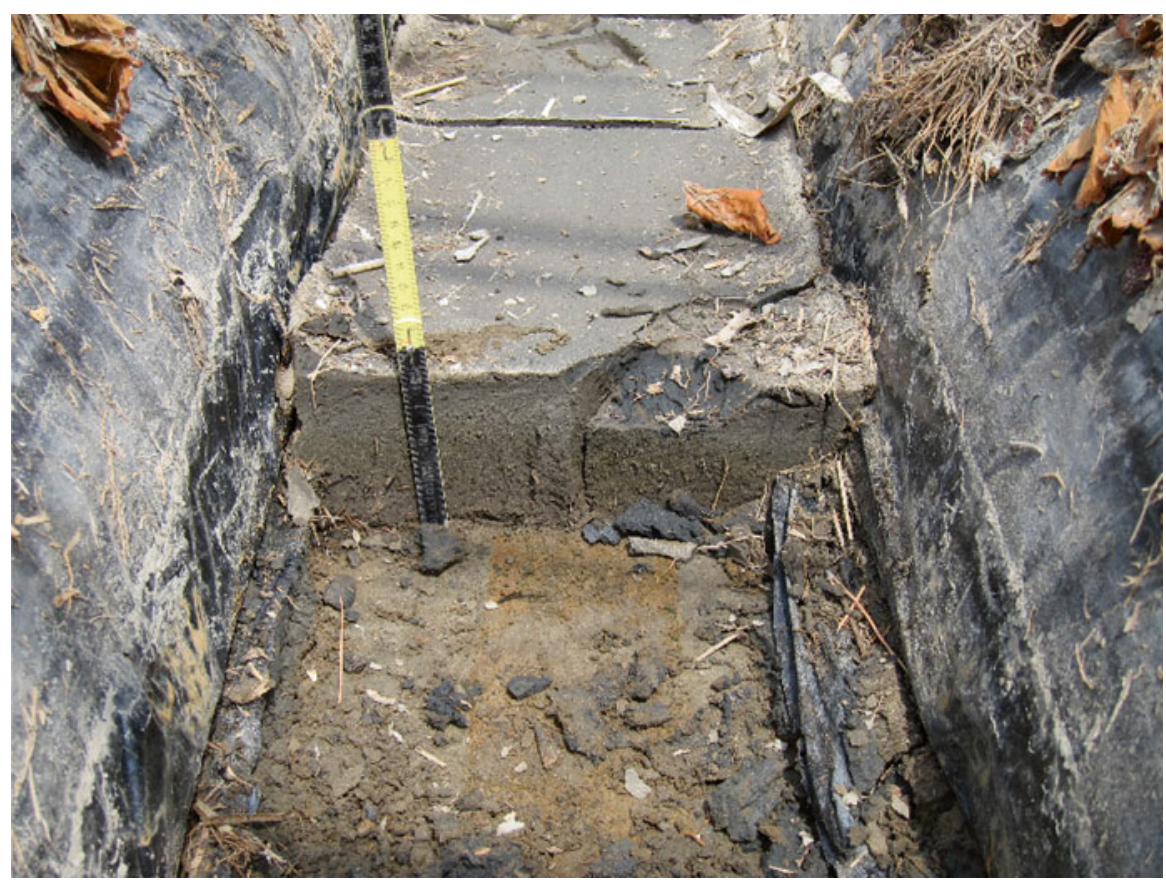

Fig. 4.3 Tsunami sediment deposited on the topsoil of a strawberry greenhouse 


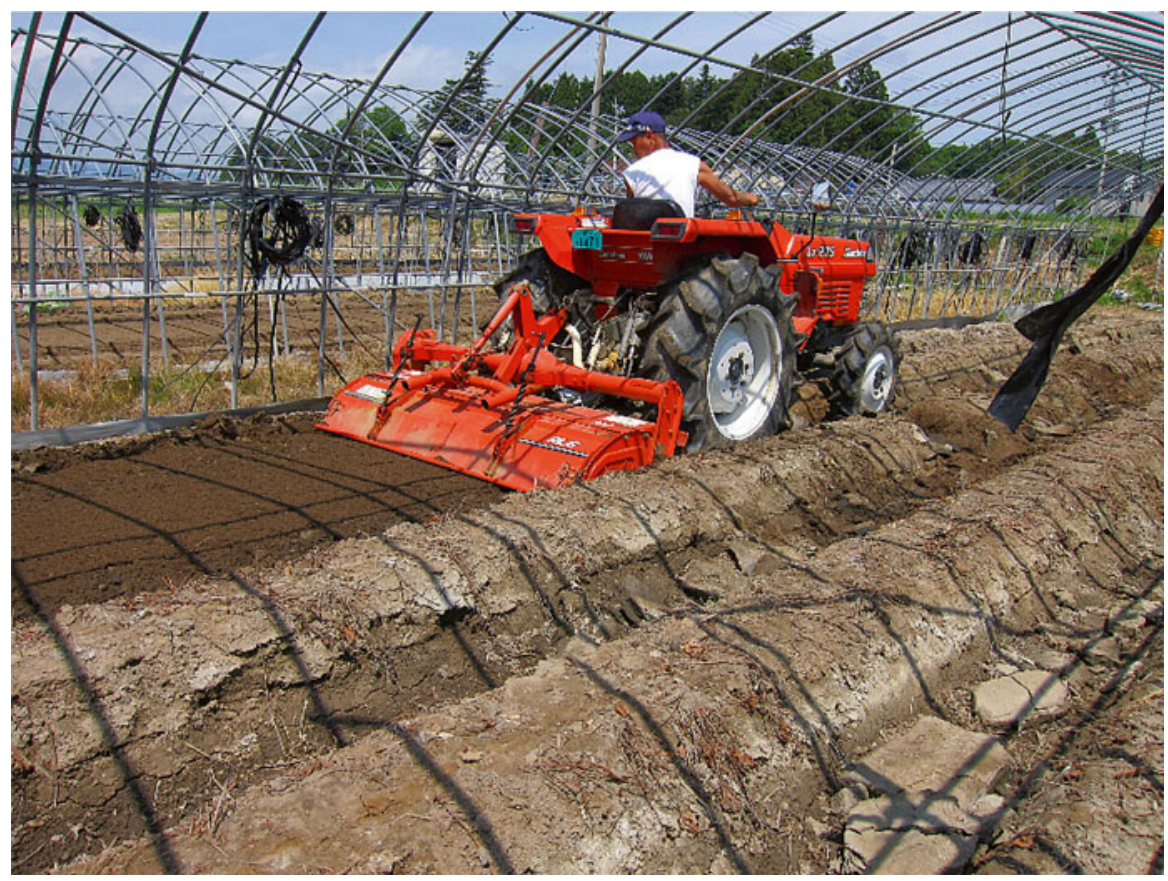

Fig. 4.4 Mixing tsunami sediment with original soil

\subsubsection{There Is No Better Salt-Remover than Rain}

Instead of removing the tsunami sediment at the strawberry farm, we mixed it with the original soil on June 16. At that time, 10 t/ha of converter slag was applied as a lime material to accelerate salt removal (Fig. 4.5). The electric conductivity (EC) in the first $10 \mathrm{~cm}$ of the surface layer decreased from $0.64 \mathrm{mS} / \mathrm{cm}$ in July to $0.35 \mathrm{mS} /$ $\mathrm{cm}$ in August, but the EC in the next $40-\mathrm{cm}$ layer from 10 to $50 \mathrm{~cm}$ decreased only to the $1.5 \mathrm{mS} / \mathrm{cm}$ level. In addition, the amount of exchangeable sodium remained at $139 \mathrm{mg} / 100 \mathrm{~g}$, with a high sodium percentage of $16.6 \%$. We therefore decided that strawberry planting should be delayed until the following year, with sorgo (a kind of green manure) planted in the meantime as a means of preparing the soil for the replanting of strawberries in September 2012. The sorgo planted on September 6, 2011 grew to almost the height of a human, reaching $1.5 \mathrm{~m}$ after a month (Fig. 4.6), and the yield of sorgo reached approximately $40 \mathrm{t} / \mathrm{ha}$. After crushing with a hammer knife mower, the sorgo was plowed into the soil with a rotary plow.

As shown in Fig. 4.7, the monthly rainfall in Soma is generally highest from June to October, and $844 \mathrm{~mm}$ of rain fell during this period in 2011. As a consequence, the amount of salt removed using rainwater alone was greater than expected. There is no better salt remover than rain. 


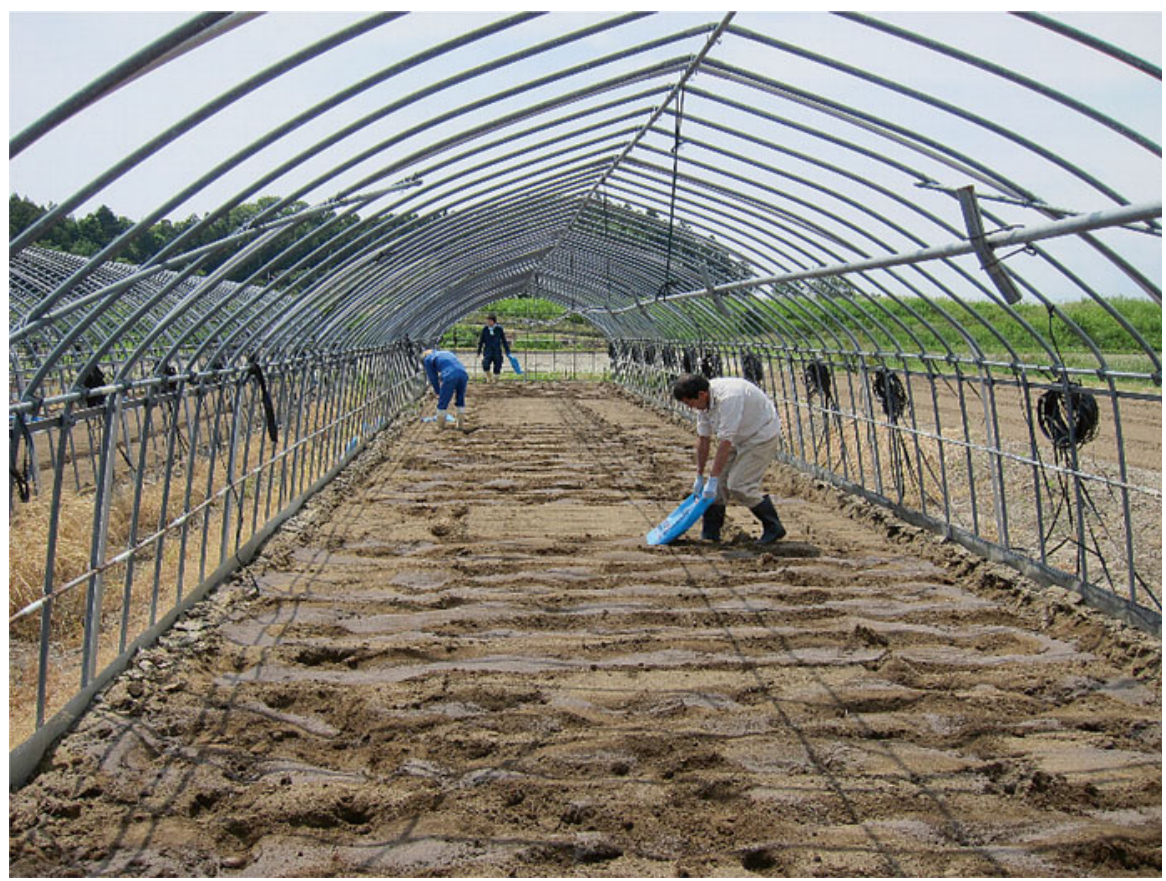

Fig. 4.5 Application of converter slag after mixing tsunami sediment with original soil
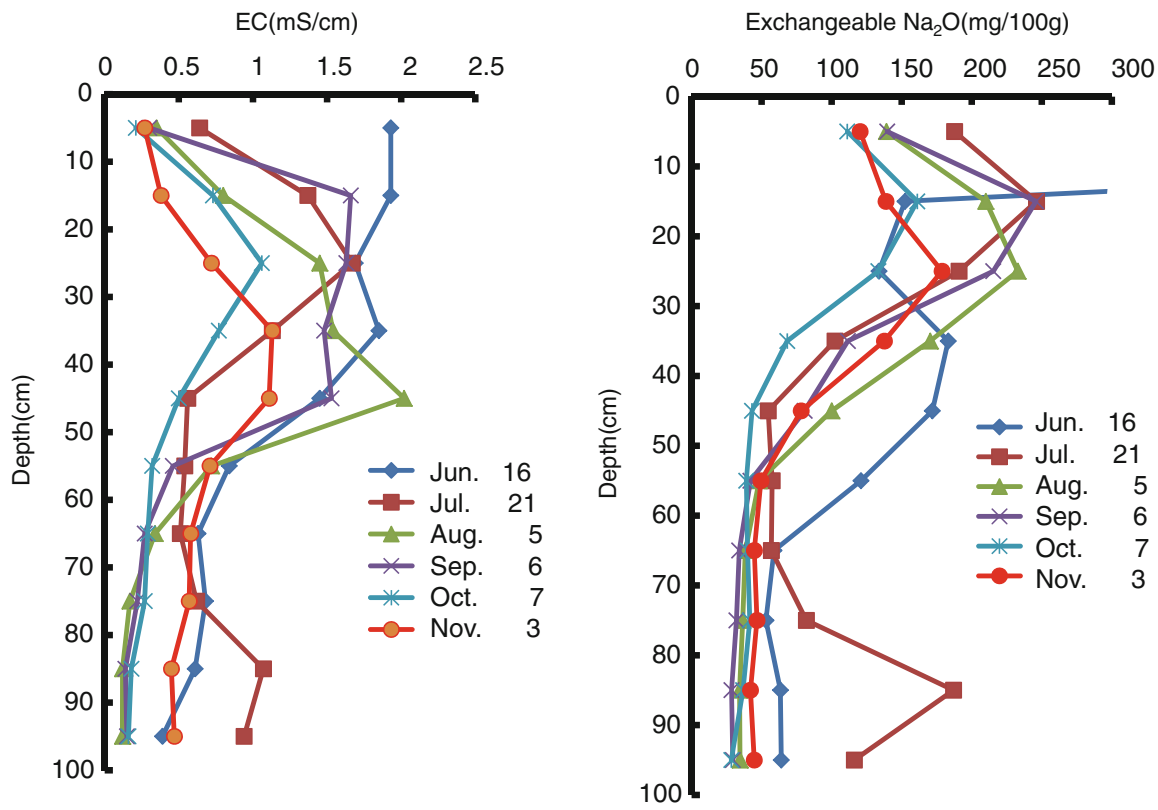

Fig. 4.6 Time-dependent changes of electric conductivity (EC) and exchangeable sodium of strawberry greenhouse soils 


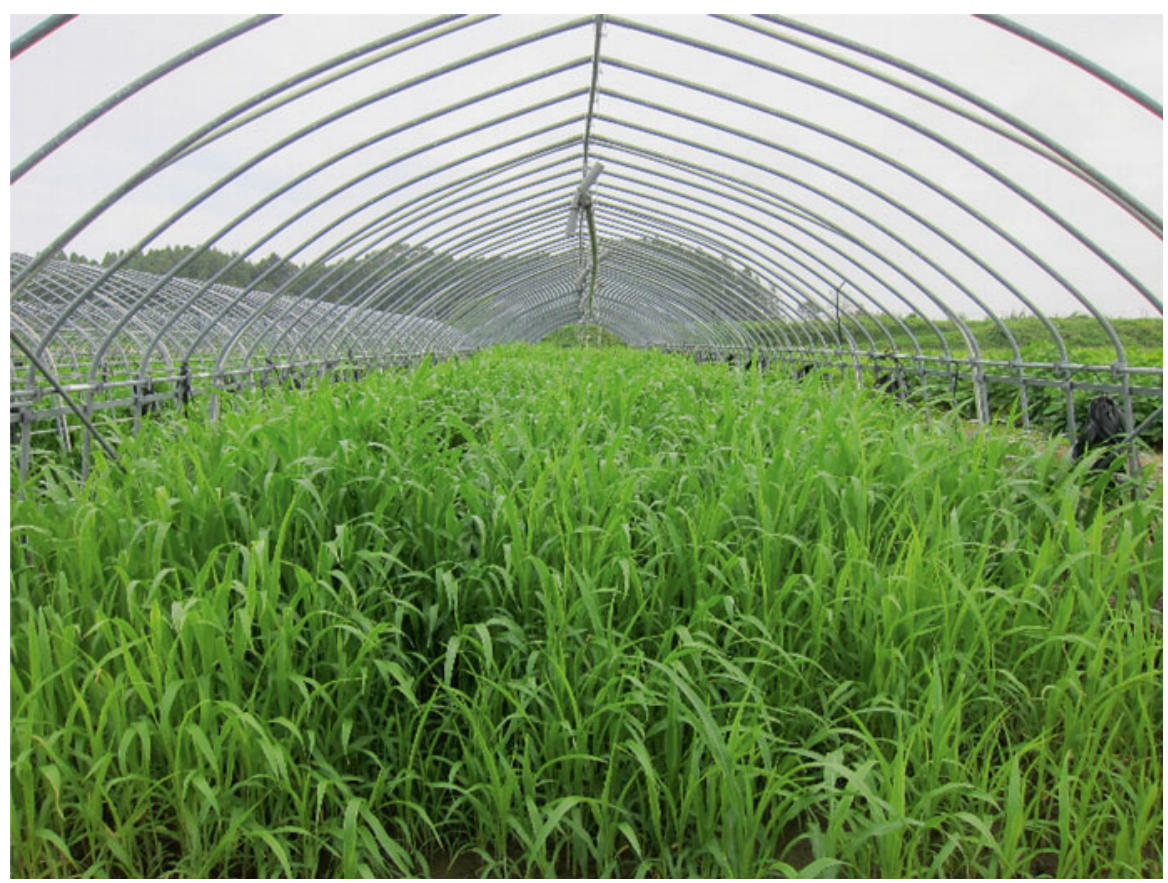

Fig. 4.7 Excellent growth of sorgo by 1 month after seeding

\subsubsection{A Discriminating Approach to Restart of Strawberry Cultivation by Soil}

Although we managed to sufficiently remove salt and adjust $\mathrm{pH}$ in the plow layer by September 2011, a high concentration of salt still remained in the lower layer, at a depth of about $40 \mathrm{~cm}$, as shown in Fig. 4.8. If the roofs of the greenhouses were replaced and strawberries planted at this stage, it was possible that the salt in the lower layer might rise into the plow layer. As strawberries are highly susceptible to the effects of salt, we pushed the strawberry planting back by a year to fall 2012. In the meantime, we planted cash crops such as spinach, turnips, and sugar snap peas instead (Fig. 4.9).

By September 2012, the salt concentration in the lower layer had also dropped, allowing strawberry seedlings to be replanted. These subsequently grew well and harvesting started in January 2013, making these the first soil-cultivated strawberries to be harvested in this strawberry-producing area, which had been severely damaged by the tsunami (Fig. 4.10). 


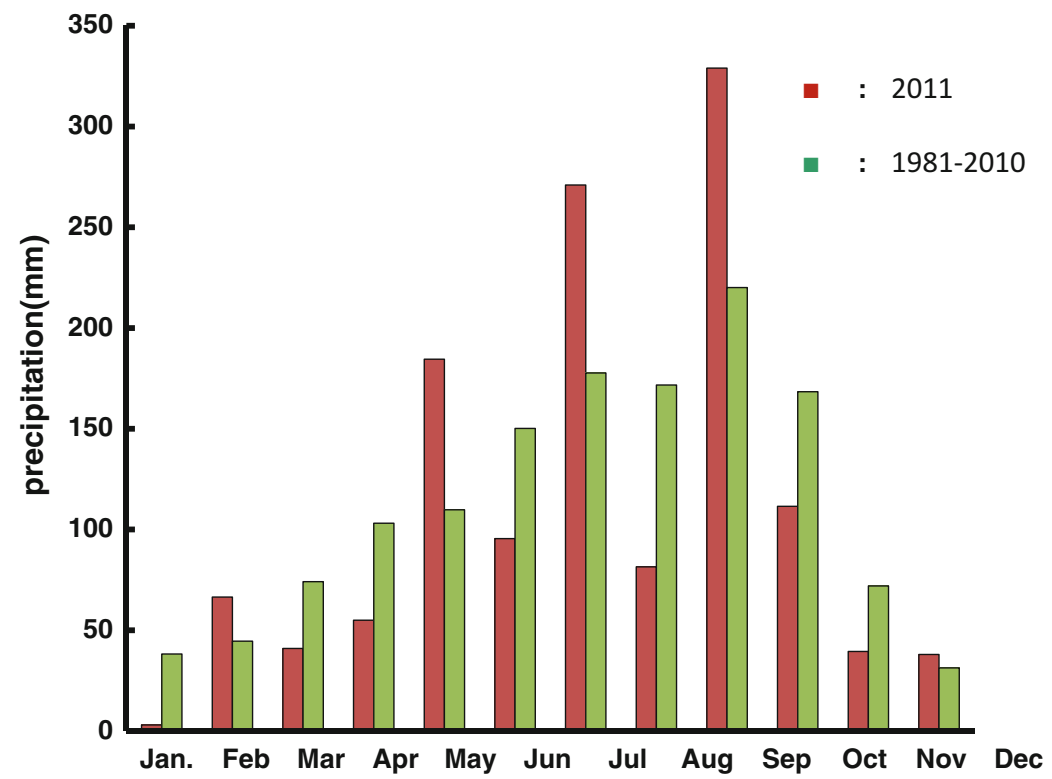

Fig. 4.8 Annual precipitation of average year and of 2011 in Soma City

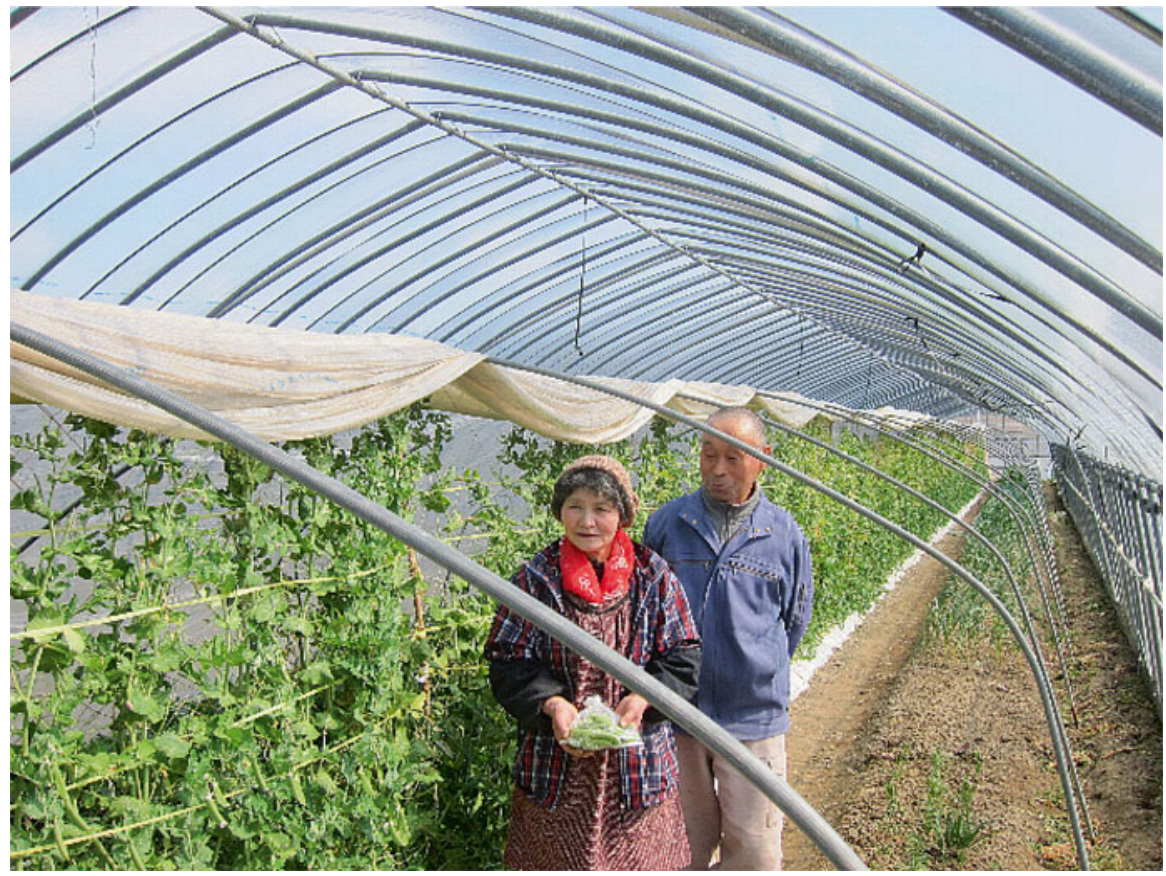

Fig. 4.9 Restart of vegetable cultivation in a strawberry greenhouse (January 2011) 


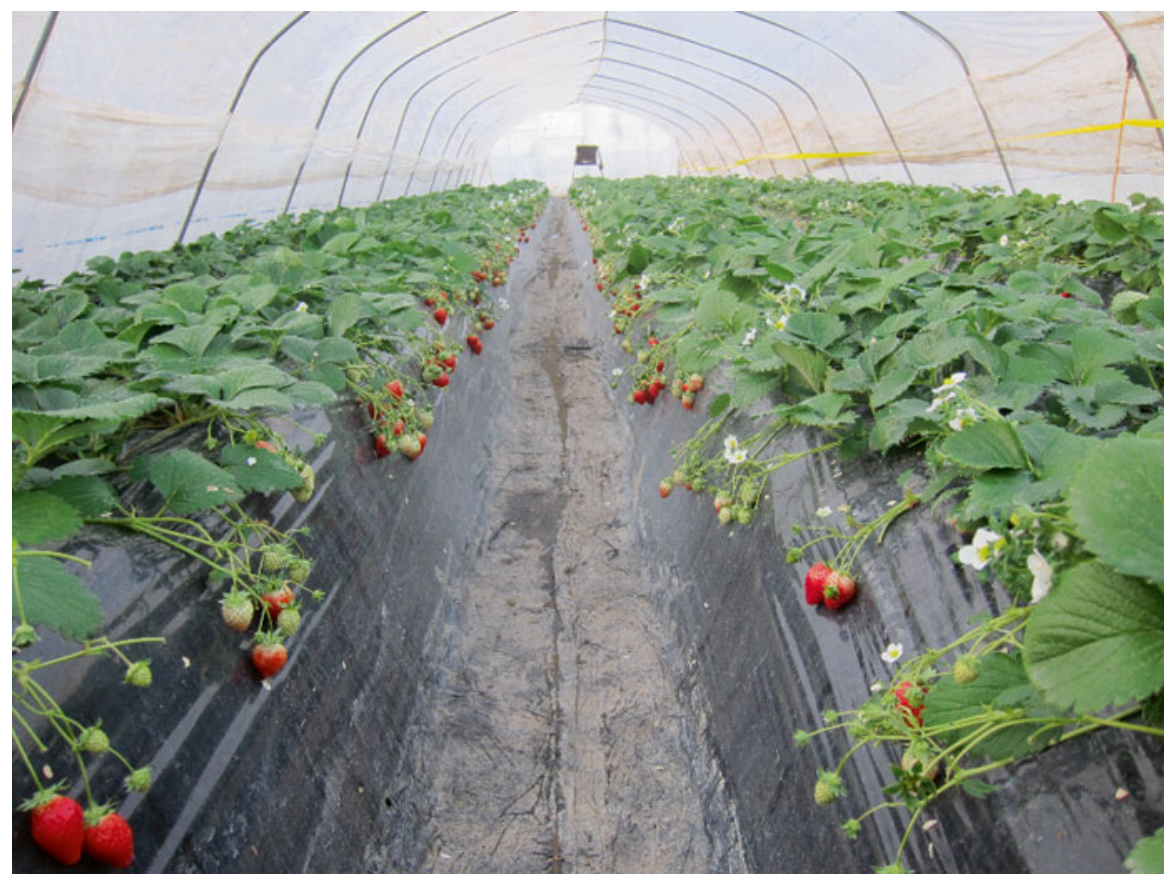

Fig. 4.10 Harvesting of strawberries was started from January 2013

\subsection{Rejuvenating Green Manure: Also Used in Hachinohe, Aomori Prefecture}

After the disasters, we were contacted by Koutaro Kimura, whom we had met at an agricultural seminar in the city of Hachinohe, Aomori Prefecture. He told us that his strawberry farm had been damaged by the tsunami (Fig. 4.11). As the Kimura farm was near the coast, the tsunami sediment was mainly sand in a layer $30 \mathrm{~cm}$ thick. We therefore advised him to mix this tsunami sand with the original soil using a power shovel and to apply converter slag. The basic salt removal method was the same as that employed in the strawberry farm in Soma. After salt removal by the rain, Aoba millet was planted as green manure instead of sorgo, as millet is more resistant to the yamase, or cold Pacific winds descending from the mountains into Hachinohe, which is situated further north than Soma. The millet planted on June 20 grew well and reached a height of $80 \mathrm{~cm}$ by July 20 (Fig. 4.12).

However, as shown in Fig. 4.13, growth was observed to be lacking in certain sections of the millet. We analyzed soil samples taken from these spots, and found residual salt in them; this residue resulted from inconsistencies in mixing the layers of soil using a power shovel, in contrast to Soma where the soil was mixed with a 


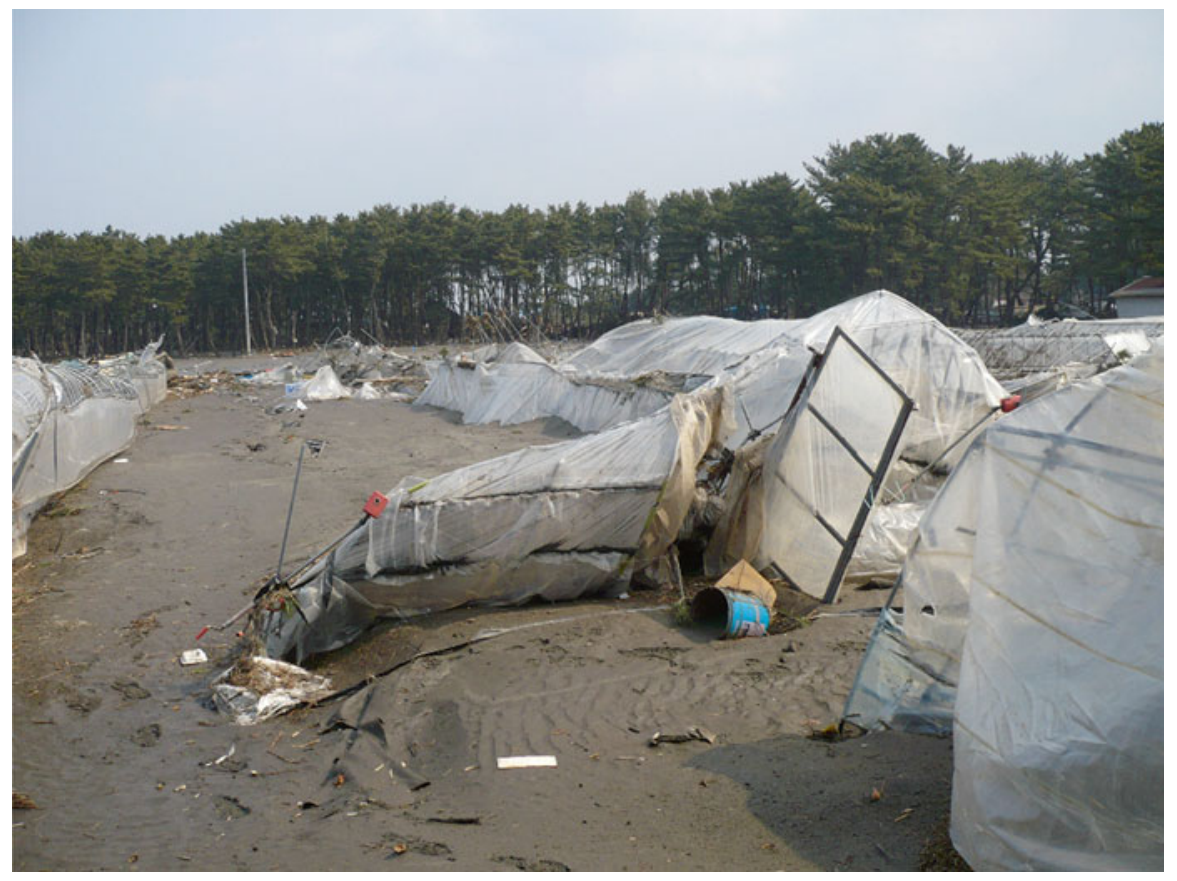

Fig. 4.11 Strawberry greenhouse of Kimura Farm struck by the tsunami in Hachinohe City, Aomori Prefecture

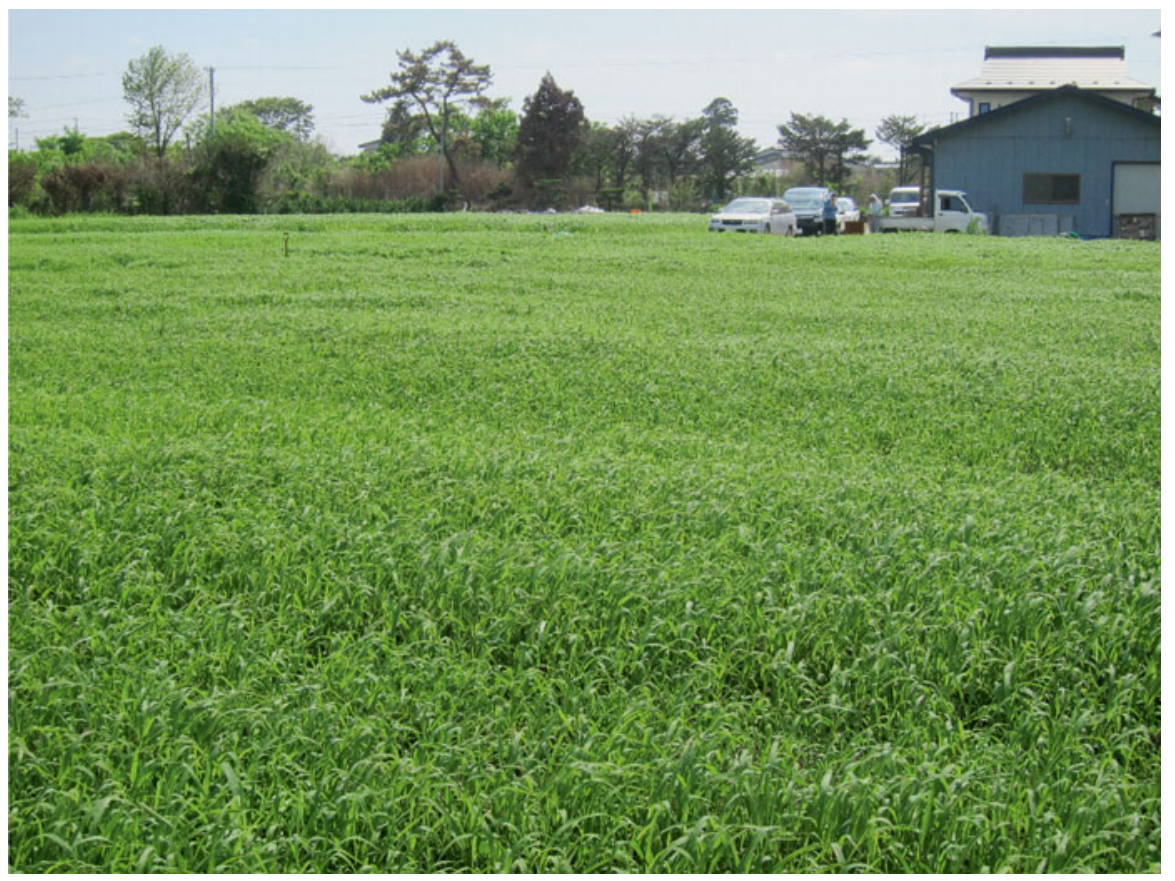

Fig. 4.12 Millet thickly covered the whole area of Kimura Farm by 3 months after being struck by the tsunami (July 2011) 

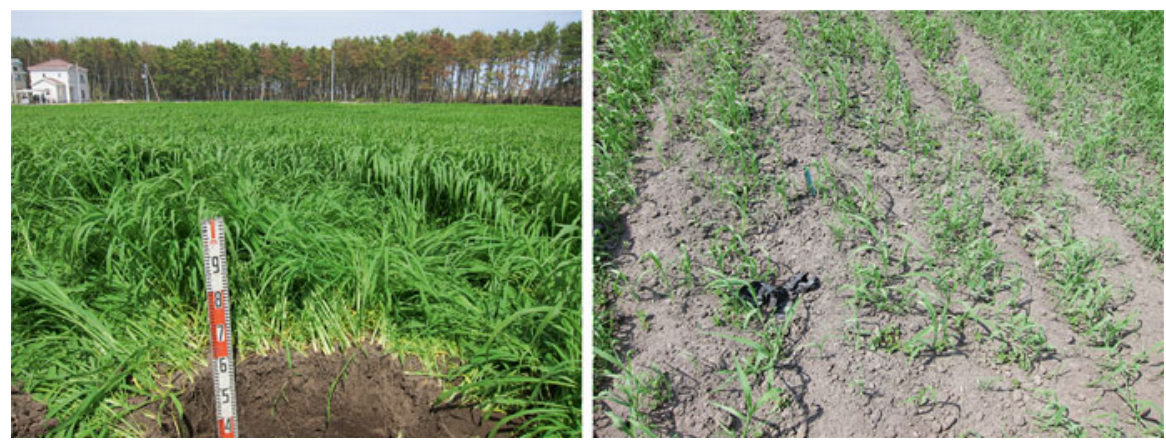

Fig. 4.13 A part that showed poor growth of millet was observed in Kimura Farm (right photograph)

rotary plow. Consequently, this discovery demonstrates the efficacy of planting green manure to confirm the removal of salt. To a farmer, such variations in growth are easier to understand than chemical analysis of the soil, and by concentrating on mixing the soil in areas that do not grow well, more uniform salt removal can be achieved. Thus, in salt-damaged farmlands, green manure serves a secondary purpose of confirming salt removal.

\subsection{Taking on the Challenge of Planting "Soma Revival Rice"}

\subsubsection{Weeds in Salt-Damaged Paddies Convince the Farmers}

Figure 4.2 shows the scene we came upon when we first visited Soma on May 1, 2011. The devastation was beyond our imagination and we thought it would probably take years to restore the land to its original state. Nonetheless, all the debris in the paddy fields had in fact been removed by September, and weeds such as barnyard grass could be seen growing here and there, even though much of the paddy surface had dried up like a tortoise shell and been reduced to a barren desert (Fig. 4.14). The tortoise shell effect was caused by sediment transported from the sea by the tsunami that had dried and cracked in a layer about $10 \mathrm{~cm}$ thick (Fig. 4.14, top right). Although no vegetation could be seen at all in the areas where tsunami sediment had accumulated, we noticed that weeds were flourishing in a line around the paddies (Fig. 4.15). Upon close examination, these lines were found to be caterpillar tracks made by machines as they entered the paddies to remove debris such as pine trees. Comparison of the soil between the caterpillar tracks and the areas without vegetation revealed that the EC and available boron level were significantly lower in the caterpillar tracks areas (Table 4.4). This discovery served to validate the 


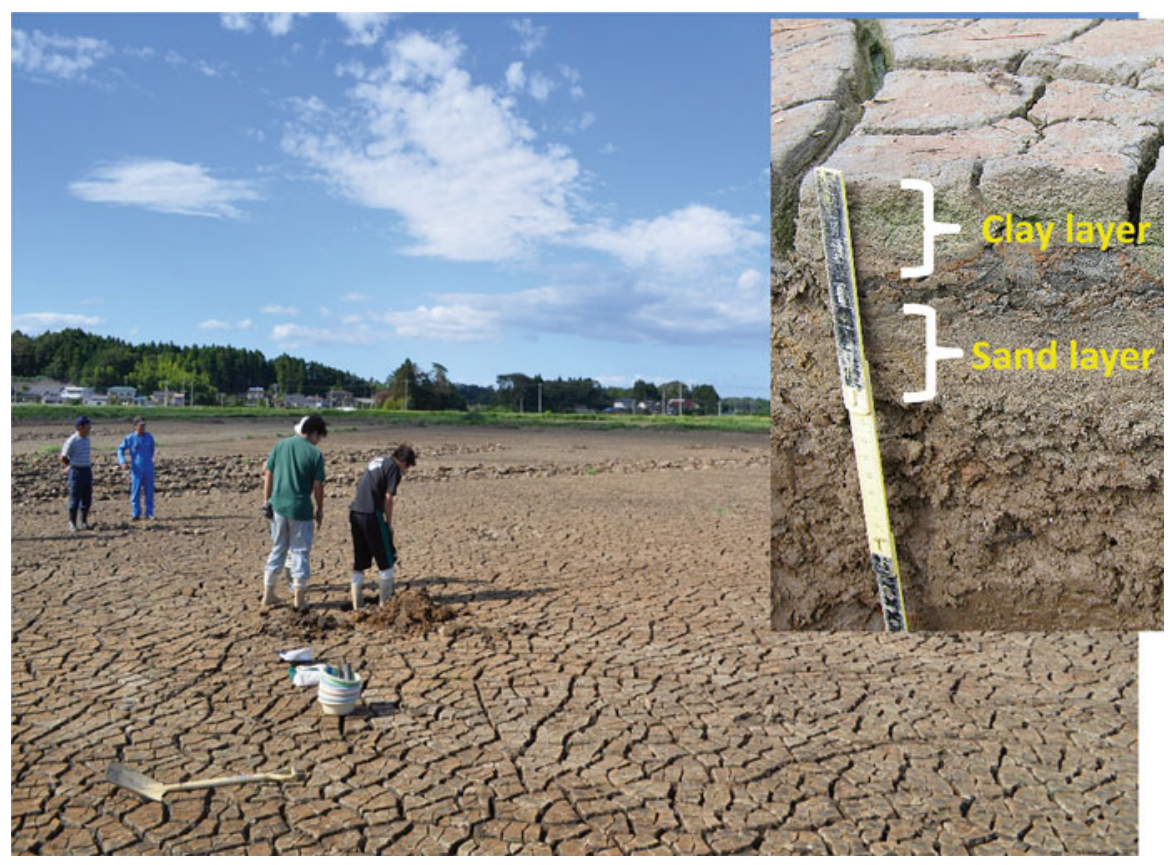

Fig. 4.14 Surface of paddy field after removal of debris in Iwanoko, Soma City, in September 2011

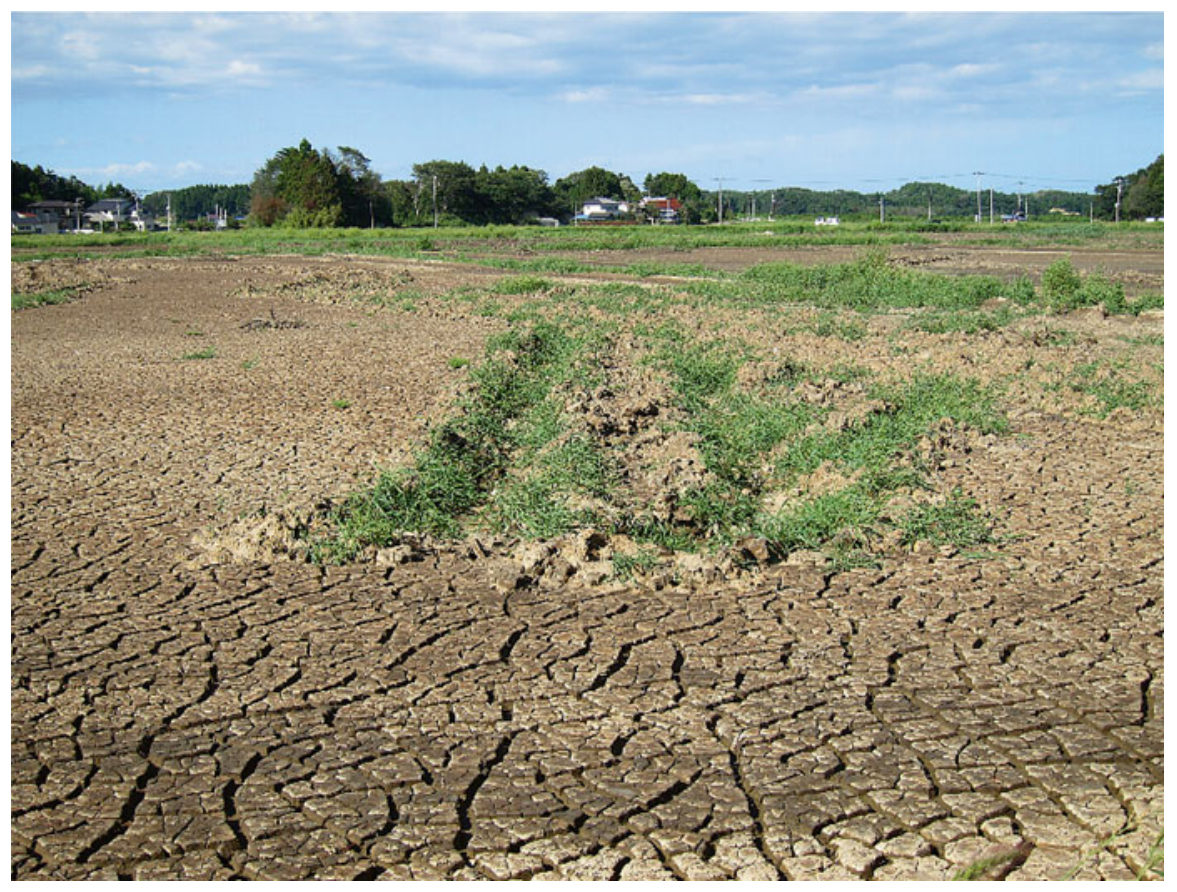

Fig. 4.15 Weeds were found linearly only on caterpillar tracks 
Table 4.4 Effects of soil mixing by movement of machines on soil chemical properties

\begin{tabular}{l|l|l|l}
\hline \multirow{2}{*}{ Sampling site } & $\mathrm{EC}$ & Exchangeable $\mathrm{Na}_{2} \mathrm{O}$ & Available B \\
\cline { 2 - 4 } & $\mathrm{mS} / \mathrm{cm}$ & $\mathrm{mg} / 100 \mathrm{~g}$ & $\mathrm{mg} / \mathrm{kg}$ \\
\hline Area without vegetation & 4.0 & 806 & 8.3 \\
\hline Area of caterpillar track & 1.9 & 275 & 1.1 \\
\hline
\end{tabular}

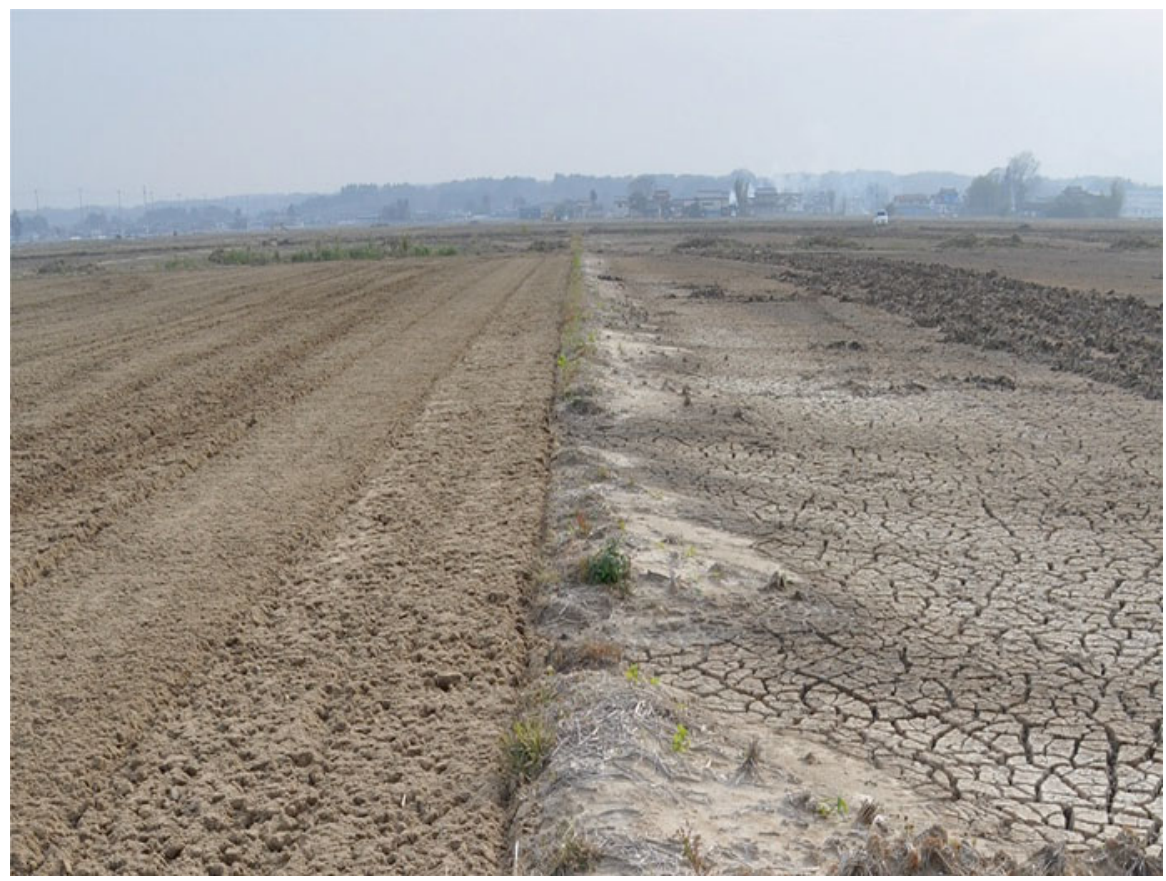

Fig. 4.16 Paddy field with mixed tsunami sediment and original soil (left of photograph) and unmixed paddy field (right of photograph)

salt removal method we had used in strawberry greenhouses, where the tsunami sediment was simply mixed with the original soil instead of being removed. Witnessing this phenomenon for themselves, the farmers decided to do the same in their paddy fields.

\subsubsection{Soil Acidification Within the Expected Range}

As shown in Fig. 4.16, tsunami sediment was mixed with the original soil in 60 ares of paddy fields on September 27, 2011, and mole drains were formed to improve water drainage toward the lower layer. Subsequently, rainwater alone was used for 


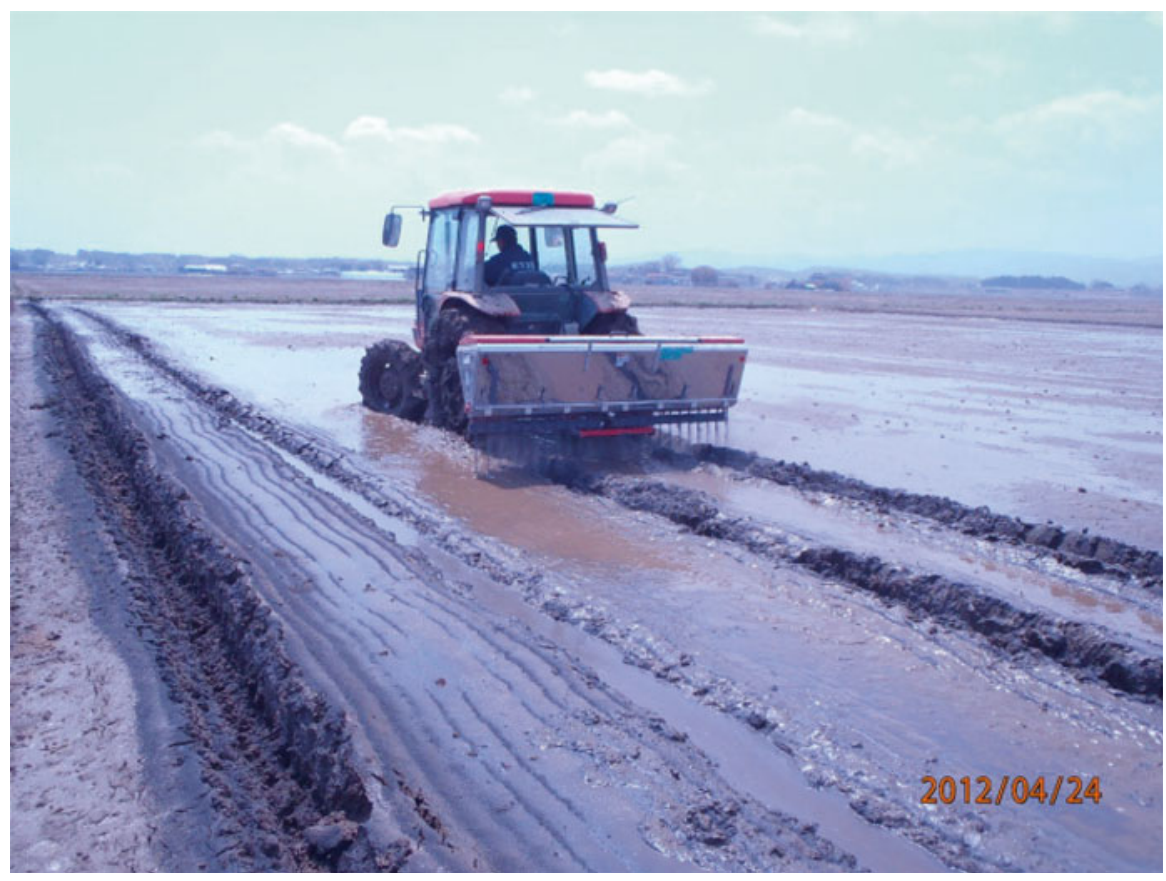

Fig. 4.17 Application of converter slag using lime sower (April 2012)

salt removal. As a result, the EC, which serves as a guide for rice planting, dropped to $0.7 \mathrm{mS} / \mathrm{cm}$ by April 3, 2012 (232 days after soil mixing). However, the pyrite in the soil had gradually oxidized until the $\mathrm{pH}\left(\mathrm{H}_{2} \mathrm{O}\right)$ dropped to 3.8, so converter slag was applied on April 23 (Fig. 4.17) to neutralize the sulfuric acid.

\subsubsection{Fields of Golden Rice Plants After a 2-Year Hiatus}

In May 2012, rice of the variety known as Hitomebore was transplanted in three plots of 1.7 ha of paddies whose salt had been removed by the aforementioned method. No fertilizer was applied as we believed that the alkaline effect resulting from the rise in $\mathrm{pH}$ value caused by the application of converter slag would cause an increase in mineralization of organic nitrogen. The rice seedlings grew extremely well after transplanting, with no inconsistencies in their growth.

On September 26, a total of $10.7 \mathrm{t}$ brown rice was harvested from the 1.7 ha of paddies (Fig. 4.18). The yield of brown rice harvested per hectare was $6.3 \mathrm{t}$, about $20 \%$ higher than the amount before the disasters. Thus, we had managed to return the rice paddies to fields of gold after a 2-year hiatus. 


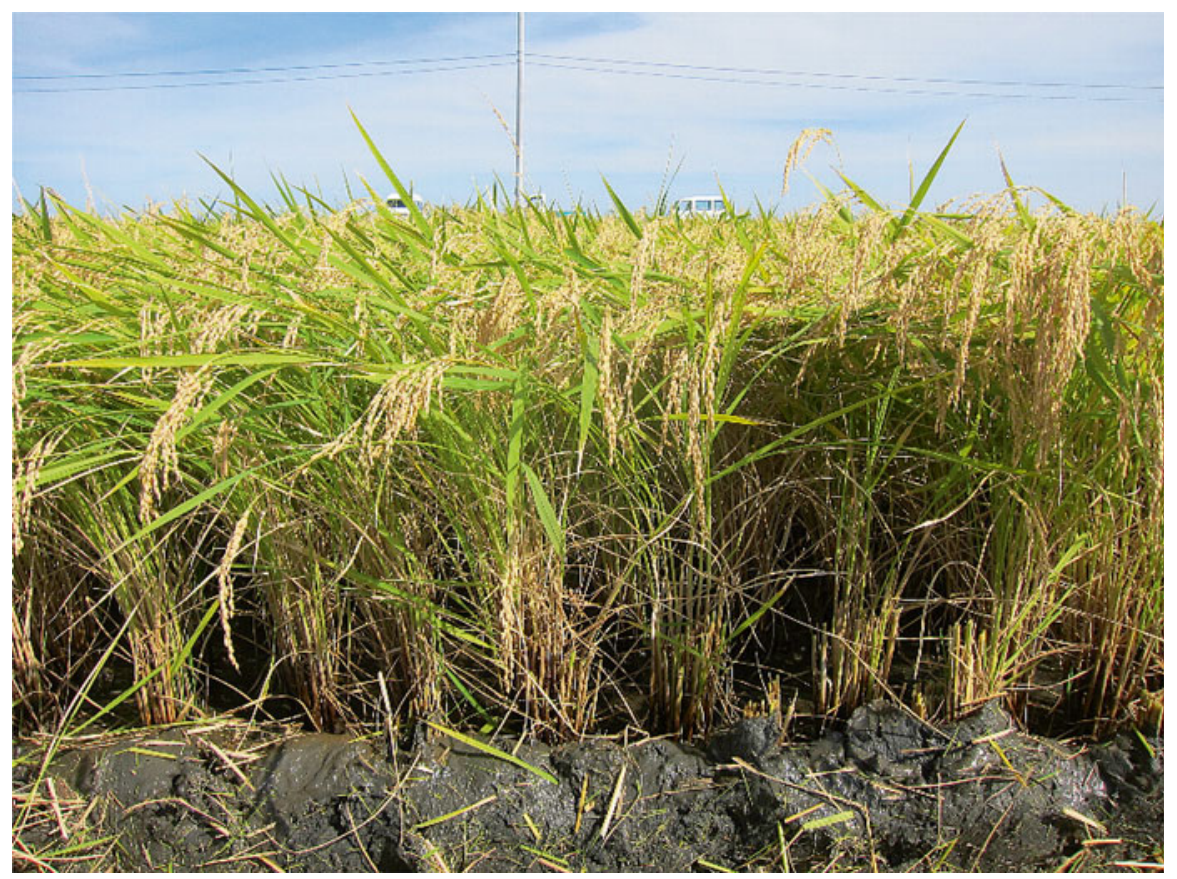

Fig. 4.18 Paddy field of golden rice plants after a 2-year hiatus (September 2011)

\subsubsection{The Highest Safety Standards for "Soma Revival Rice"}

The city of Soma is located about $40 \mathrm{~km}$ from the Fukushima Daiichi nuclear power station. A radioactive cesium level of about $750 \mathrm{~Bq} / \mathrm{kg}$ was detected in soil taken from paddies that produced this first crop of the rice that we were to call "Soma Revival Rice." However, not only was there no trace of radiation detected in the brown rice, but even the stems and leaves, which absorb radiocesium more easily than the grains, showed no trace of radiation at all. As cesium and potassium belong to the homologous elements, when a large quantity of potassium (exchangeable potassium of $25 \mathrm{mg} / 100 \mathrm{~g}$ or more) exists in the soil, it has been known to suppress the absorption of cesium by the rice. As the paddy soil mixed with tsunami sediment contained about $60 \mathrm{mg} / 100 \mathrm{~g}$ of exchangeable potassium, the process of mixing in the tsunami sediment had ended up suppressing radioactive cesium absorption by the rice.

The levels of harmful elements such as cadmium and arsenic measured in the rice itself were $0.01 \mathrm{mg} / \mathrm{kg}$ for cadmium and $0.04 \mathrm{mg} / \mathrm{kg}$ for arsenic (Table 4.5). In the case of cadmium, this was significantly lower than the $0.4 \mathrm{mg} / \mathrm{kg}$ that is the nationally stipulated limit in Japan. Although there is no limit set for arsenic, the level measured was only one-quarter of the $0.16 \mathrm{mg} / \mathrm{kg}$ average for rice produced in Japan. On the other hand, when levels of "healthy" minerals were compared with 
Table 4.5 Cadmium, arsenic, and radioactive cesium concentration of "Soma Revival Rice"

\begin{tabular}{l|l|l|l|l|l|l}
\hline & \multicolumn{3}{l}{ Stem and leaf } & \multicolumn{2}{l}{ Brown rice } \\
\cline { 2 - 7 } Sample & ${ }^{134} \mathrm{Cs}$ & ${ }^{137} \mathrm{Cs}$ & ${ }^{134} \mathrm{Cs}$ & ${ }^{137} \mathrm{Cs}$ & $\mathrm{Cd}$ & As \\
\hline Soma Revival Rice & N.D. & N.D. & N.D. & N.D. & $0.02 \mathrm{mg} / \mathrm{kg}$ & $0.04 \mathrm{mg} / \mathrm{kg}$ \\
\hline
\end{tabular}

Table 4.6 Mineral content of "Soma Revival Rice” (brown rice bases mg/100 g)

\begin{tabular}{l|l|l|l|l|l|l|l|l|l}
\hline Sample & $\mathrm{Na}$ & $\mathrm{Mg}$ & $\mathrm{P}$ & $\mathrm{K}$ & $\mathrm{Ca}$ & $\mathrm{Mn}$ & $\mathrm{Fe}$ & $\mathrm{Cu}$ & $\mathrm{Zn}$ \\
\hline Soma Revival Rice & 1.6 & 144 & 365 & 266 & 8.6 & 2.4 & 2.3 & 0.3 & 2.1 \\
\hline Standard value $^{\mathrm{a}}$ & 1.0 & 110 & 290 & 230 & 9.0 & 2.1 & 2.1 & 0.3 & 1.8 \\
\hline
\end{tabular}

aStandard tables of food composition in Japan

levels in the Standard Tables of Food Composition in Japan, the rice was found to contain higher levels of magnesium, phosphorous, and potassium (Table 4.6).

\subsection{The Soma Project Expands Use of the Soma Method}

\subsubsection{The Project Launches}

In total, 1,100 ha of farmland were affected by the tsunami in Soma, and only 140 ha were being farmed again by March 2013, the bulk of this being areas that suffered relatively minor damage. Of the farmland that was devastated by large volumes of debris and accumulated tsunami sediment, only a fraction had been restored and just 1.7 ha were the paddies we had rehabilitated using the Soma Method. We aimed, therefore, to restart farming on a larger scale by expanding the use of the Soma Method from an isolated 1.7-ha point on the map to a larger 50-ha area in 2013.

We therefore submitted a proposal and obtained the consent of the Soma City authority and JA Soma (the local agricultural cooperative) to launch the Soma Project. Subsequently, a representative of all three parties involved in the project requested the CEO of Japan's largest steelmaker, Nippon Steel \& Sumitomo Metal Corporation, to help by supplying $450 \mathrm{t}$ of converter slag at no cost, which the CEO promptly granted.

\subsubsection{The Project Gets Under Way}

On March 8, 2013, press conferences to announce the converter slag donation by Nippon Steel \& Sumitomo Metal Corporation were held in Tokyo (Tekko Kaikan) and Soma's City Hall (Fig. 4.19). 


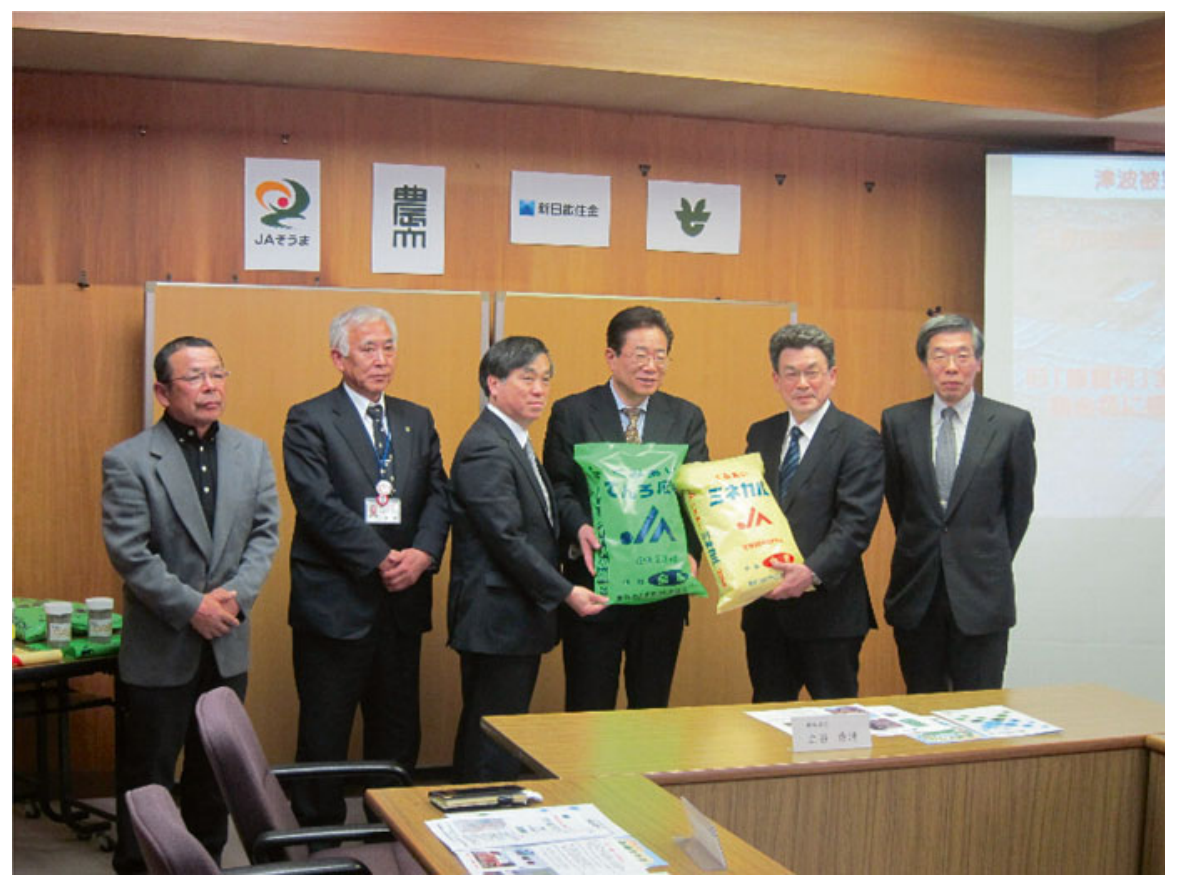

Fig. 4.19 Press conferences of Soma Project in Soma City Hall (March 2013)

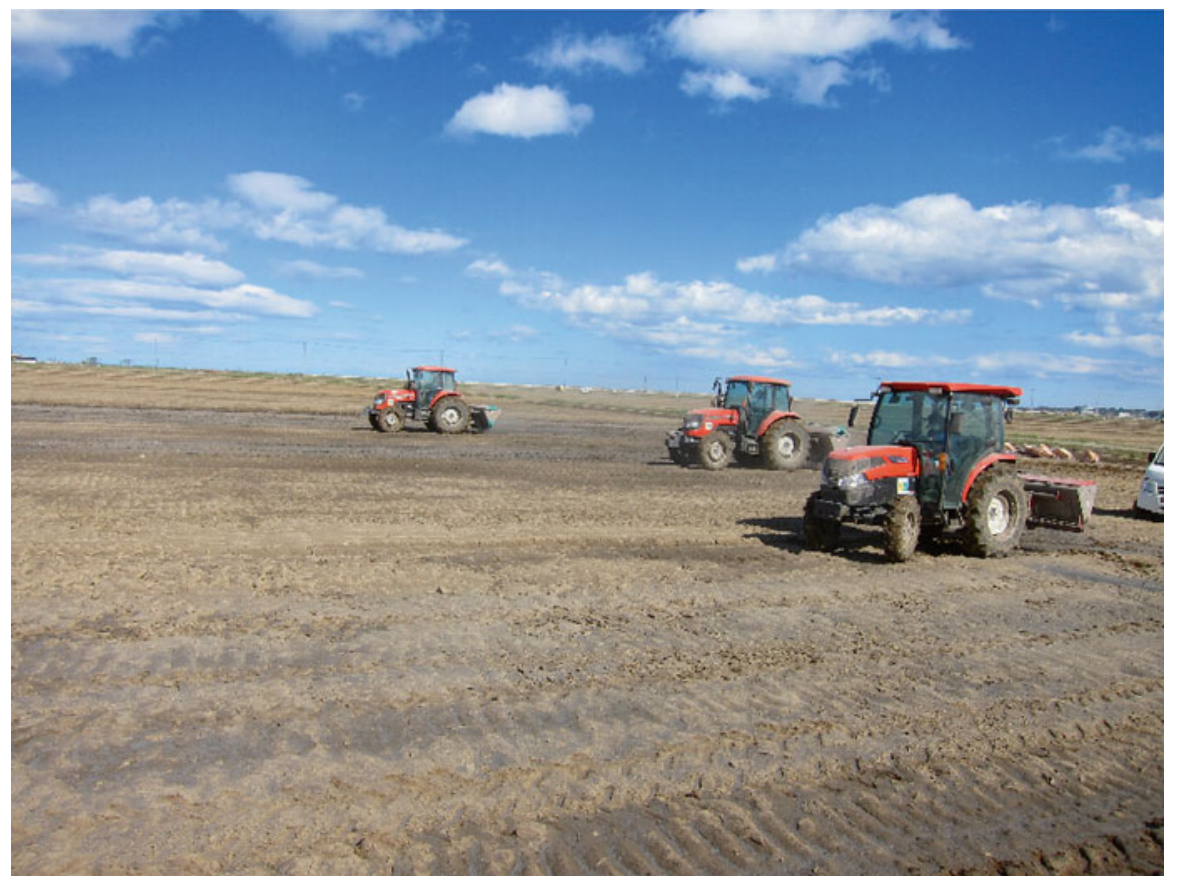

Fig. 4.20 Application of converter slag using lime sower by collaboration of farmers (April 2013) 


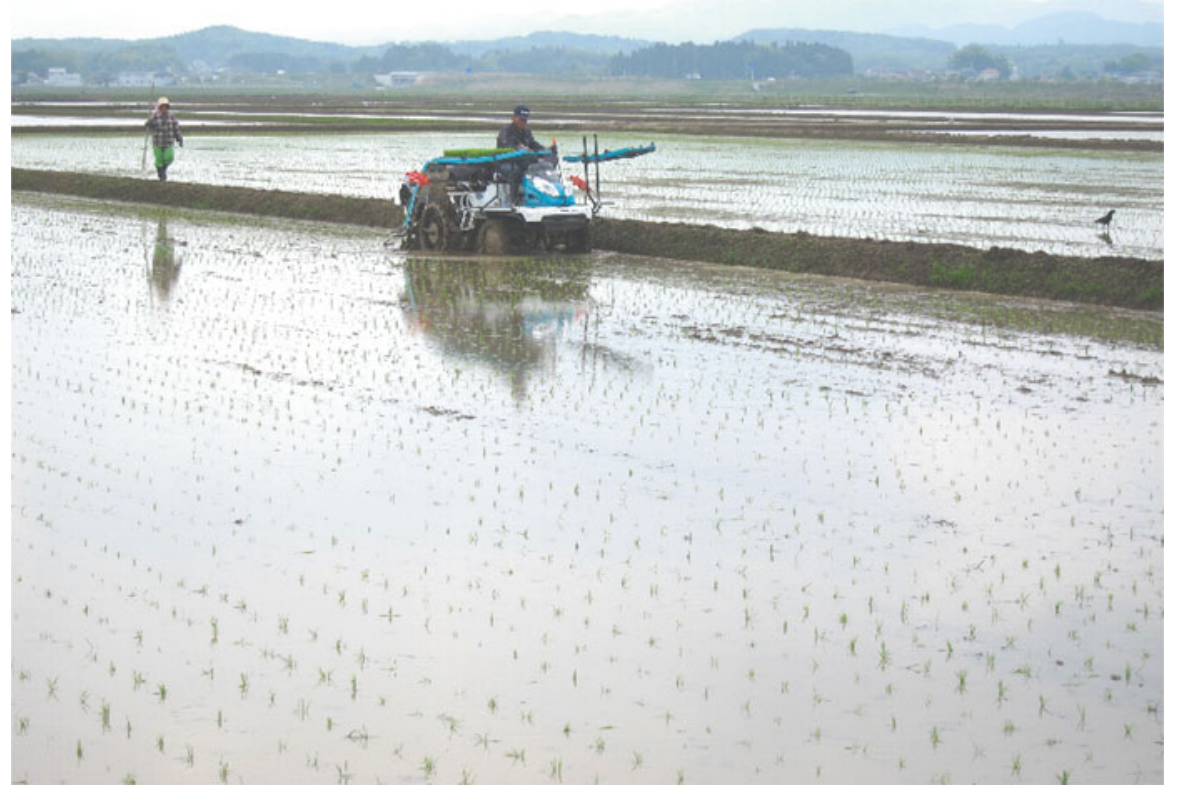

Fig. 4.21 Rice planting was started in all the paddy fields of the Soma Project (May 2013)

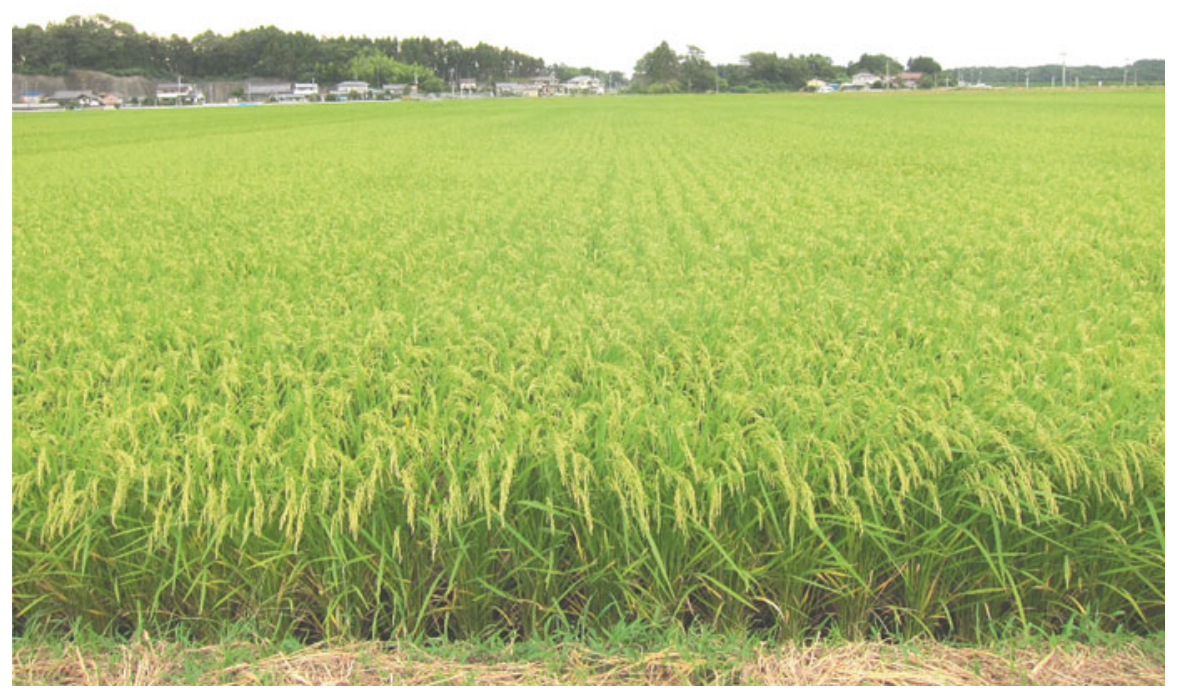

Fig. 4.22 Gold-tinged ears of rice have started to droop down (August 2013) 
In April, the Soma City Hall prepared a warehouse in Soma Port to accept a large amount of converter slag transported by 10-t trailers. At around the same time, the farmers started cultivating rice seedlings. Beginning April 19, a large tractor fitted with three lime sowers was used by the farmers to start scattering converter slag and mixing it into the soil (Fig. 4.20). Subsequently, the farmers flooded the paddy fields and wet tilled the land. Rice planting was then started in all the paddy fields from May onward (Fig. 4.21). In some paddies where the EC had been high, the farmers passed irrigation water through after the rice was planted. Thanks to these measures, the rice flourished without any problems, and as of August 30, gold-tinged ears of rice have started to droop down, ready to be harvested from mid-September onward (Fig. 4.22).

Open Access This chapter is distributed under the terms of the Creative Commons Attribution Noncommercial License, which permits any noncommercial use, distribution, and reproduction in any medium, provided the original author(s) and source are credited. 